\title{
Mature Vegetation along Roads
}

O. Hykš*

Department of Transport Systems, CTU in Prague, Faculty of Transportation Science, Na Florenci 25, Prague

*Corresponding author: hyks@fd.cvut.cz

K. Neubergová

Department of Transport Systems, CTU in Prague, Faculty of Transportation Science, Horská 3, Prague

DOI: $10.2478 /$ trans-2014-0009

\begin{abstract}
The article deals with the issue of vegetation, particularly mature vegetation, along transport routes. Since rather heated discussions on this topic have recently appeared, particularly in relation to road safety, the authors of this article decided to present this issue in wider context and from various viewpoints. The starting point for this issue is mentioned in the introduction. The next part deals with the history of planting tree alleys in the Czech Republic. Subsequently, a brief summary of advantages and drawbacks of mature vegetation along transport routes is presented. The next part of the article discusses the environmental bases and, last but not least, the article deals with the impact of mature vegetation on road safety.
\end{abstract}

KEY WORDS: Vegetation, roads, safety.

\section{INTRODUCTION}

Planting mature vegetation along transport routes is becoming a centre of interest and an issue for discussion between staunch advocates and equally staunch opponents. In case an accident with fatal consequences occurs, whose cause is a collision with a solid obstacle - a tree, opinions appear that trees are dangerous and need to be completely removed. On the other hand, vegetation along transport routes has a wide range of benefits and inherently fits in the European landscape. The article aims to point out positive as well as negative effects of mature vegetation along transport routes and discuss possible bases. The results of the article do not and cannot provide unambiguous conclusions - mature vegetation yes or no, the given issue is too extensive for such conclusion.

\section{HISTORY OF PLANTING MATURE VEGETATION ALONG ROADS}

Great changes in landscape occurred in our country particularly during the medieval colonization in the $13^{\text {th }}$ and $14^{\text {th }}$ century. A large number of villages and towns were founded at that time and the road network was growing. The landscape was gradually becoming more and more civilized, and this process got even more intensive under the reign of Charles IV. This ruler was a founder of paved roads, since he realized their importance. The first planting of trees along those roads appeared at that time. On the other hand, at that time as well as later 
in the $17^{\text {th }}$ century, trees were often removed not to provide a hiding place for robbers and other criminals. For example historical sources state that vegetation should be as distant from the road as a "stone throw encircled by fingers" (Bulír, 1988). Planted tree alleys, which were established in open landscape, came only in the second half of the $17^{\text {th }}$ century. Thus in the Baroque period the landscape, devastated by the Thirty Year's War, got gradually more civilized. Also, small architecture elements in the form of small chapels or wayside shrines started to appear in the landscape. These elements very often accompanied by solitary trees and follow-up tree alleys, which connected them to villages, hamlets, and to general surroundings.

Regarding mature vegetation planting along transport routes, an edict was published in 1752 which brought obligation to plant trees along all new roads. Therefore, most of the tree alleys were planted under the reigns of Maria Theresa and Joseph II, when fruit trees became popular as well. However, the reasons for planting were not only economic, but also focused on orientation, safety, and aesthetics.

The planting of tree alleys continued in the $19^{\text {th }}$ century, when building of the secondary roads network began, and the law ordered to plant tree lines and alongside these roads, consisting especially of fruit trees. The planting also continued in the $20^{\text {th }}$ century. When field boundaries were ploughed and non-forest vegetation was gradually removed in the $1950 \mathrm{~s}$, tree alleys along transport routes were often the only remaining sanctuaries for many animals and migration corridors for a large number of animal species. Therefore, the accompanying vegetation became the only planted vegetation apart from forests, and its popularity was also brought to urban areas.

\section{TYPES OF ACCOMPANYING VEGETATION}

The vegetation along transport routes can be divided into six groups (Cimbůrková \& Šerá, 2011). The first type is a tree alley. Its advantage is a relatively low consumption of planting material and easy planting, the disadvantage particularly concerns over-aging, related to insufficient or unsuitable maintenance. The second type is an area-wide planting, which is particularly applied to newly built motorways and around grade-separated junctions. The third group is a forest vegetation, which is not specifically planted, but rather relates to transport routes cutting through the existing forest areas.

Another type is natural vegetation, i.e. vegetation grown by natural succession. This accompanying vegetation is particularly formed by fast growing woody plants and its advantage lies mostly in the cheap initial investment, which is however compensated by the need of corrective interventions. Another type of vegetation, bush stripes, is used for motorway central reserves. The last group of accompanying vegetation is grass vegetation, which is often used in combination with the previous types. Grass vegetation has a soil improvement and retention function and plays an important role for protecting soil from erosion.

When planting accompanying vegetation, apart from other features, it is necessary to consider the type of road. The accompanying vegetation should correspond to the surrounding landscape and respect the local conditions. Planting monotonous tree alleys, which make drivers tired, is not recommended for motorways, expressways and firstclass roads. More suitable is to combine mature and low vegetation in irregular intervals, so that the monotonous character of the road is broken up and drivers' attention is maintained.

Regarding second-class roads, which are closely bound to local environment, the accompanying vegetation should be in accord with the character of the local landscape and support specific features of the given area. Therefore, on the one hand, the accompanying 
vegetation can underline views to the landscape and support important dominant features, and on the other hand, it can cover up undesirable views.

Regarding third-class roads, lower speeds allow drivers to notice more of a local environment, thus it is advisable to plant different groups of woody plants, while it is still necessary to take into account the local conditions and the surrounding landscape.

\section{BENEFITS OF MATURE VEGETATION ALONG TRANSPORT ROUTES IN TERMS OF IMPACT ON THE ENVIRONMENT}

The accompanying vegetation has a number of functions. Regarding its environmental function, it is a production of $\mathrm{O}_{2}$, absorption of $\mathrm{CO}_{2}$, interception of PM. The impact of tree and bush vegetation on PM reduction is based on a number of factors:

- absolute area of leaf surface,

- leaf surface quality,

- leaf position,

- movability of leaves,

- tree crown shape,

- sediment character.

In addition, vegetation plays an important role concerning hydrology, since it works as a protection of embankments and dykes, reinforcing them and protecting them from erosion. Vegetation also has a positive impact on water retention in landscape and thus reduces consequences of torrential rains.

Another advantage of mature vegetation along transport routes is its impact on reducing cross wind to vehicles and retention of snow, which prevents the creation of snowdrifts on roads.

The aesthetic function is also not negligible, since accompanying vegetation improves the road integration in landscape, and last but not least, it provides shade. In addition, trees significantly influence climate of the local environment.

As mentioned above, vegetation along roads often creates the only suitable biotope for a large number of animals in a certain area and provides connection to the surrounding environment, which greatly improves conditions for animal migration. For example, thanks to the accompanying vegetation, meadow vole was able to spread to the distance of $90 \mathrm{~km}$.

The tree lines and alleys are also places where a large number of birds live, e.g. redwing and yellowhammer. This original inhabitant of forest-steppes found a sanctuary in the Czech agricultural landscape; in bushy field boundaries and in tree alleys along roads.

Another example of an animal bound to this environment is the hermit beetle. This beetle, just $25 \mathrm{~mm}$ long, develops in tree hollows. It is very rare in the Czech Republic and is listed among protected species and included in the protection system of NATURA 2000. Its protection is also supported by the European Union, which also supported a programme of the extensive planting of trees along roads in three Polish regions in 2010 and 2011.

\section{IMPACT OF MATURE VEGETATION ON ROAD SAFETY}

It is the issue of the relationship between mature vegetation along transport routes and safety that is discussed so much today. In the case of a collision of a vehicle with a solid obstacle, i.e. a tree, the consequences are often tragic. Nevertheless, the approach to "cut down everything and solve the problem" is over-simplifying it and the issue deserves a deeper analysis.

There is currently a lot of research in progress concerning the relationship between accidents and trees. This issue has two solutions. The first one is the care of the existing tree 
alleys. The other one concerns new planting along newly built roads, but here we deal with the issues of maintenance or financing. In addition, vegetation along transport routes is affected by traffic. Furthermore, there is an issue of planting indigenous species or introducing foreign species to the landscape.

The advantages of tree alleys along transport routes include easier anticipation of direction, when mature vegetation outlines the course of the road. Alleys also help to estimate distance and optically guide the driver. The advantages also include easier orientation in fog and in darkness, keeping drivers alert, and prevention of vehicle falling.

Some of the most serious drawbacks concern the danger of collision with a solid obstacle, and the increased risk of an accident due to leaves or fruit on the road surface. Inappropriately planted or maintained vegetation can also lead to limited visibility at junctions or inner sides of horizontal curves. Other negative effects include the risk of falling branches and dazzling of drivers due to changes of light and dark sections covered by tree crowns.

The following tables and graphs deal with the types of road accidents and their consequences in relation to trees along transport routes.

Table 1: Statistics of road accidents for last 5 years - total number of accidents.

\begin{tabular}{|c|c|c|c|c|c|c|c|}
\hline Year & $\begin{array}{c}\text { Total } \\
\text { number } \\
\text { of RAs on all } \\
\text { roads }\end{array}$ & $\begin{array}{c}\text { Total number } \\
\text { of RAs - } \\
\text { collision with } \\
\text { solid obstacle }\end{array}$ & $\begin{array}{c}\text { Total number } \\
\text { of RAs - } \\
\text { collision with } \\
\text { solid obstacle } \\
\text { (excl. trees) }\end{array}$ & $\begin{array}{c}\text { Total number } \\
\text { of RAs - } \\
\text { collision with } \\
\text { solid obstacle } \\
\text { (collision with } \\
\text { tree) }\end{array}$ & $\begin{array}{c}\text { Total number } \\
\text { of RAs - } \\
\text { collision } \\
\text { with solid } \\
\text { obstacle (\%) }\end{array}$ & $\begin{array}{c}\text { Total number } \\
\text { of RAs - } \\
\text { collision with } \\
\text { solid obstacle } \\
\text { (excl. trees } \\
\text { (\%)) }\end{array}$ & $\begin{array}{c}\text { Total number } \\
\text { of RAs - collision } \\
\text { with solid } \\
\text { obstacle (collision } \\
\text { with tree (\%)) }\end{array}$ \\
\hline $\mathbf{2 0 0 9}$ & 74815 & 17779 & 14774 & 3005 & 23.8 & 19.8 & 4.1 \\
\hline $\mathbf{2 0 1 0}$ & 75522 & 16894 & 14429 & 2465 & 22.4 & 19.1 & 3.3 \\
\hline $\mathbf{2 0 1 1}$ & 75137 & 18134 & 15466 & 2668 & 24.2 & 20.6 & 3.6 \\
\hline $\mathbf{2 0 1 2}$ & 81404 & 19261 & 16427 & 2834 & 23.7 & 20.2 & 3.5 \\
\hline $\mathbf{2 0 1 3}$ & 84398 & 19626 & 17016 & 2610 & 23.3 & 20.2 & 3.1 \\
\hline
\end{tabular}

(Where RA .... road accident)

(Source: authors; Policie ČR, 2014)

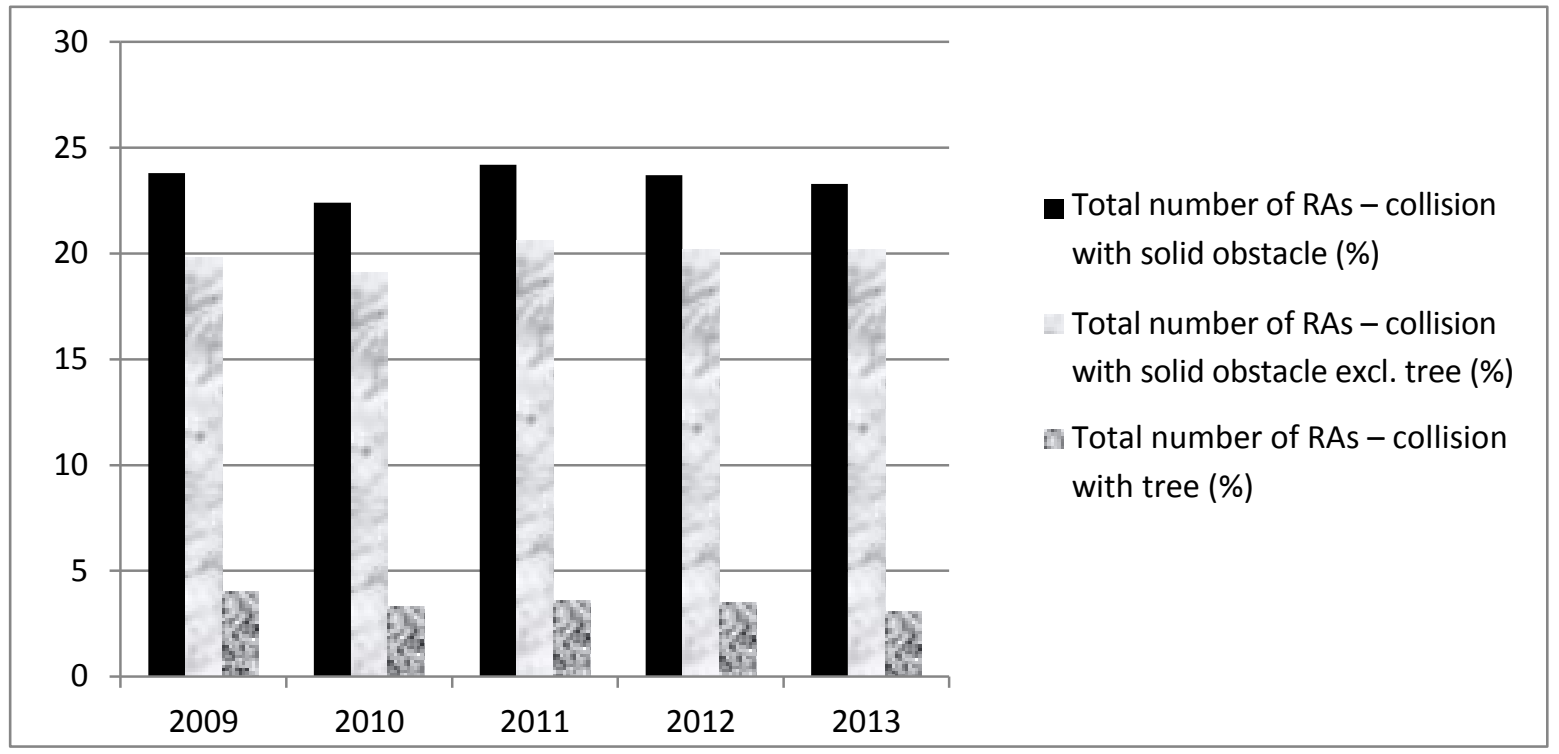

Figure 1: Statistics of road accidents for last 5 years - total number of accidents. (Source: authors) 
Table 1 shows the total number of road accidents on Czech roads and, for comparison, the total number of accidents with solid obstacles and the number of accidents with trees are shown. To be more illustrative the data are also shown in percentages and in graphic form (see Figure 1).

Table 2 shows data on mortality rate on Czech roads. Again, the data are shown in absolute values as well as in percentages and the Table is complemented with graphics (see Figure 2).

Table 2: Statistics of road accidents for last 5 years - total number of accidents.

\begin{tabular}{|c|c|c|c|c|c|c|c|}
\hline Year & $\begin{array}{c}\text { Total } \\
\text { number of } \\
\text { RAs on all } \\
\text { roads }\end{array}$ & $\begin{array}{c}\text { Total number } \\
\text { of RAs - } \\
\text { collision with } \\
\text { solid obstacle }\end{array}$ & $\begin{array}{c}\text { Total } \\
\text { number } \\
\text { of RAs - } \\
\text { collision } \\
\text { with tree }\end{array}$ & $\begin{array}{c}\text { Total number } \\
\text { of fatalities } \\
\text { on all roads }\end{array}$ & $\begin{array}{c}\text { Total number of } \\
\text { fatalities - } \\
\text { collision with } \\
\text { solid obstacle } \\
\text { (\%) }\end{array}$ & $\begin{array}{c}\text { Total number of } \\
\text { fatalities - } \\
\text { collision with } \\
\text { solid obstacle } \\
\text { excl. tree (\%) }\end{array}$ & $\begin{array}{c}\text { Total number of } \\
\text { fatalities - } \\
\text { collision with } \\
\text { (\%) }\end{array}$ \\
\hline $\mathbf{2 0 0 9}$ & 74815 & 17779 & 3005 & 832 & 27.2 & 11.3 & 15.9 \\
\hline $\mathbf{2 0 1 0}$ & 75522 & 16894 & 2465 & 753 & 24.9 & 9.6 & 15.3 \\
\hline $\mathbf{2 0 1 1}$ & 75137 & 18134 & 2668 & 707 & 22.5 & 7.6 & 14.9 \\
\hline $\mathbf{2 0 1 2}$ & 81404 & 19261 & 2834 & 681 & 26 & 9.4 & 16.6 \\
\hline $\mathbf{2 0 1 3}$ & 84398 & 19626 & 2610 & 583 & 26.4 & 11.7 & 14.7 \\
\hline
\end{tabular}

(Where RA .... road accident)

(Source: authors; Policie ČR, 2014)

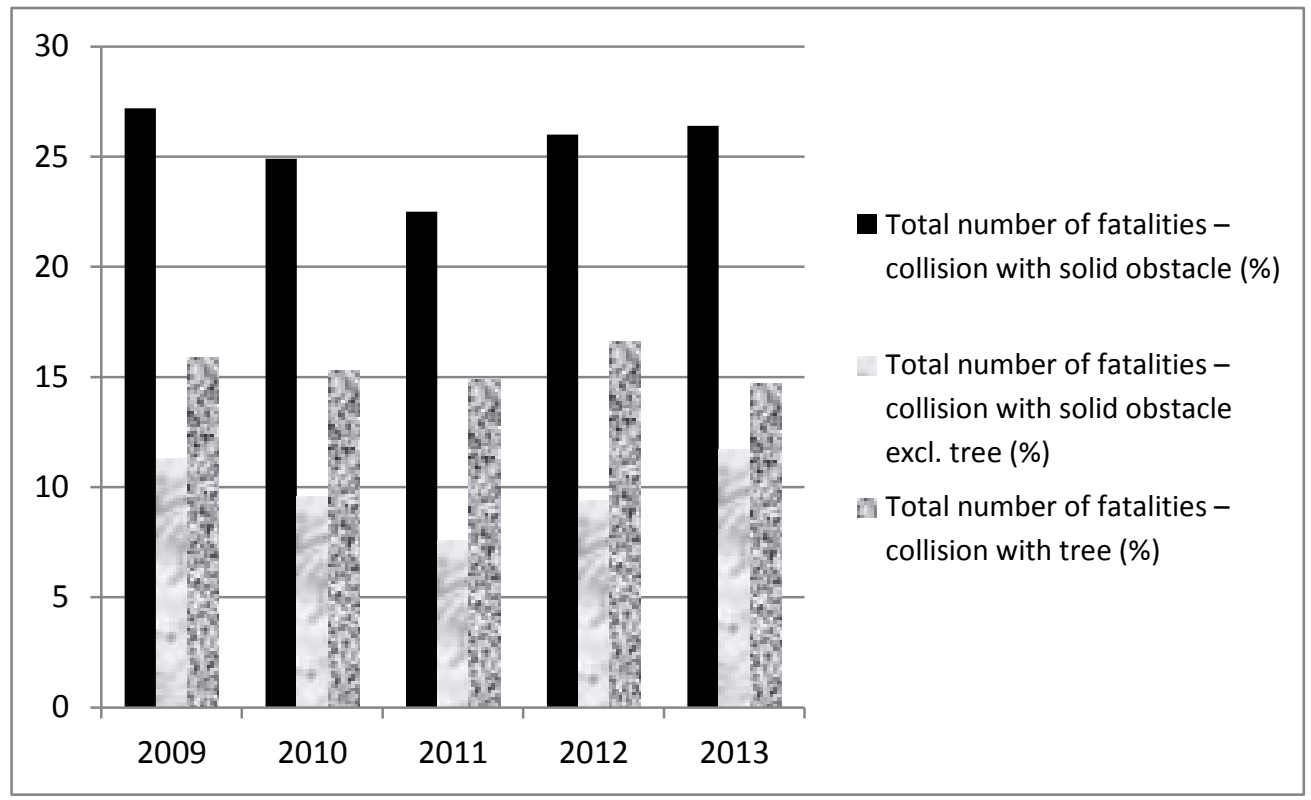

Figure 2: Statistics of road accidents for last 5 years - mortality rate.

(Source: authors)

The Tables and Graphs show the danger of trees along transport routes. Although the share of road accidents - collision with a tree only reaches 3 to $4 \%$ of all accidents, its share in mortality rate reaches from 14 to $17 \%$. However, these numbers cover also collisions with solitary or inconveniently planted trees. 
To conclude, the planting of bush vegetation along transport routes has a very positive impact on roads themselves, when the bush vegetation reduces the effects of cross wind and formation of snowdrifts, as well as on the surrounding environment, when the accompanying vegetation allows the road to fit better into the adjacent landscape. In addition, it creates in the Czech agriculture landscape a suitable and often the only biotope for a large number of animals.

Regarding mature vegetation, it is necessary to pay attention to road safety and particularly the distance of trees from the road. German research found that a 2-metre distance of trees from the road side does not make the accident consequences more severe than those on roads without trees. However, if we start making this distance smaller, the severity of accident consequences increases dramatically, and once the distance of trees from the road side reaches $0.5 \mathrm{~m}$, the severity of consequences doubles. In the Czech Republic, the distance of trees from roads was already specified in standard ČSN 736101 Projektování silnic a dálnic (Design of highways and motorways) from 1957. The smallest permitted distance of a tree trunk from the road side was $2.5 \mathrm{~m}$; later this distance was increased to $4.5 \mathrm{~m}$ (Švédová, 2010). Regarding the distance of mature vegetation planting along transport routes, the standard contains a graph specifying distance by road types. Furthermore, the standard includes the information that trees may not be planted on traffic islands, in sight fields, in protection zones of technical networks, at sites where it may obstruct visibility of road signs, etc.

The approaches to road safety vary in different European countries. For example, fullgrown trees along transport routes were cut down in a massive scale for safety reasons in Germany in the 1950s. Approximately 50000 kilometres of tree alleys had been removed by 1999 (Skalský, 2010). However, it became gradually clear that the landscape gets too monotonous and drivers are at risk of cross winds. Therefore, new planting started in 1990. This planting is accompanied by a campaign for better road safety with the emphasis on driving in tree alleys.

In Sweden tree alleys are a protected biotope (Skalský, 2010). And in Japan strips of vegetation are designed and planted 10 years before a road is put in operation, so that it would have its functions immediately (Oneyama et al., 1999). The research of relationships between road safety and accompanying mature vegetation is described in a large number of studies. Interesting results were brought by a study conducted in France (Pradines \& Marmier, 2011), which, on the basis of surveys from 43 French departments, shows that there is no correlation between the data on road safety risks and the number of trees in alleys.

Mature vegetation along transport routes has formed the character of Czech landscape for centuries. As early as in 1632, Albrecht von Wallenstein had a four-row linden tree alley planted from the town of Jičín to Libosad. Thus it is necessary to make any interventions with great care. Tragic consequences of road accidents when a vehicle hits a tree are undeniable fact. The consequences of road accidents caused by a collision with a solid obstacle, particularly a tree, are described in Chapter 5, which summarizes statistics of road accidents for the last 5 years. The data in tabular and graphic form are obvious, but it is necessary to bear in mind that trees are not the ones that kill, but the driver's inattention or error is.

Collisions of motor vehicles with solid obstacles, e.g. trees, are a serious safety issue. As some research studies and experience show, in ideal cases roads should be designed without accompanying hazardous objects. However, this condition is difficult to meet and thus a compromise needs to be found. Regarding newly built transport routes, the situation is easier since mature vegetation can be planted in a sufficient distance from roads and grass and bush vegetation can be planted next to the road. Optimal distance of trees from roads is a subject of a large number of research studies, whose results vary. For example in Austria, the distances 
of trees at motorways are set to $4.75 \mathrm{~m}$ and at fist-class roads to $2.0 \mathrm{~m}$ (Simonová et al., 2007). The question is the distance of trees from each other. Historically, a patent from 1752 set the distance to 6 fathoms, which was 11 metres. Regarding safety, the optimum distance seems to be $40 \mathrm{~m}$, but here we can hardly consider such distance a compact tree alley. Therefore planting is recommended with the distance of $25 \mathrm{~m}$ (Simonová et al., 2007), if possible, along a single side of the road and on the external side of horizontal curves. This recommendation correlates with other recommendations, when different sceneries do not have as tiring effect on drivers as a monotonous alley. On the other hand, driving through a tree alley makes drivers instinctively slow down. In Austria an increase in the number of road accidents occurred due to speeding on a monitored road section after the tree alley had been removed.

The situation is different with tree alleys along the existing roads. In these locations it is necessary to perform sufficient dendrological research and regular maintenance. Regarding safety, these tree alleys should always be accompanied with road safety measures, e.g. installation of suitable road signs, speed reduction, application of reflective marks and reflectors on trees, installation of crash barriers at horizontal curves. In addition, drivers' education cannot be neglected. In Germany drivers are taught as early as at driving schools to drive through tree alleys. In the Czech Republic, at least the tradition of reflective markings with a reflective paint on tree bark, which was common before 1989, becomes popular again.

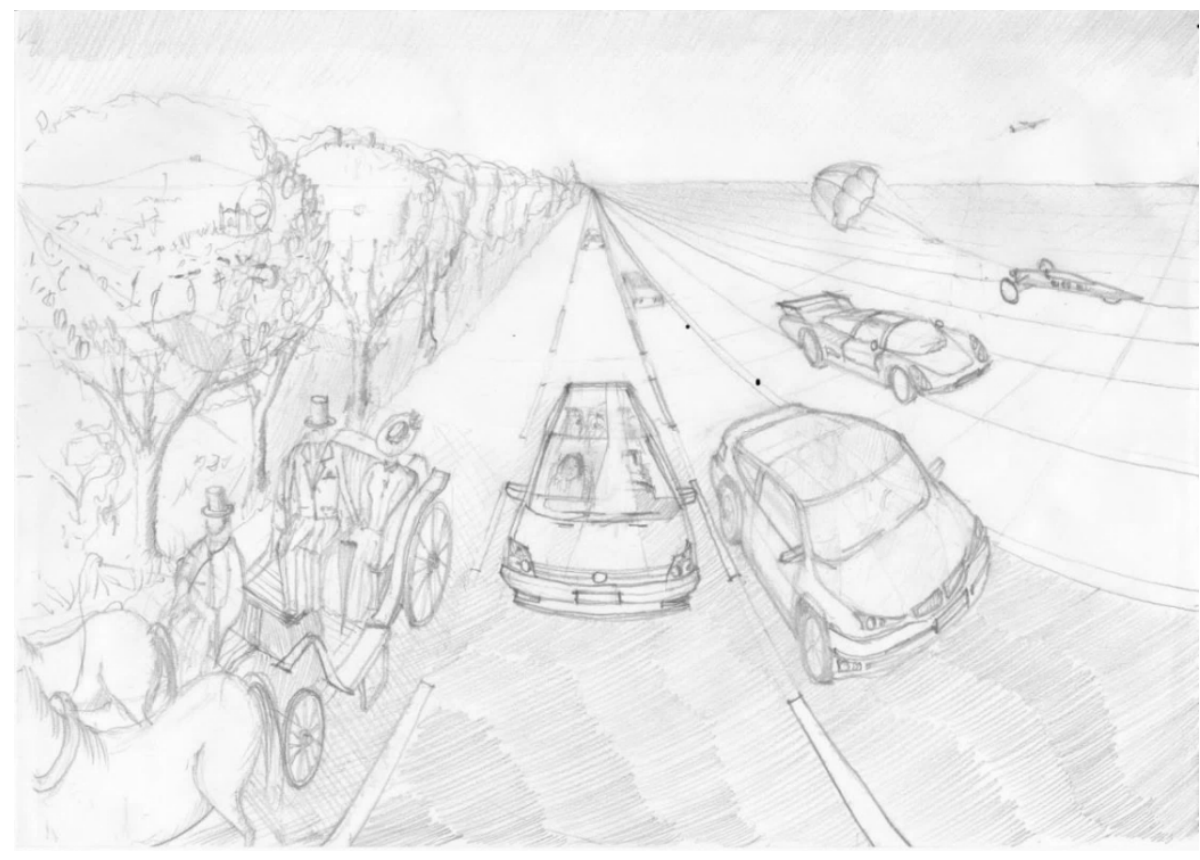

Figure 3: Vegetation along a transport route.

(Source: authors)

\section{REFERENCES}

Bulír, P., 1988. Vegetační doprovody silnic. Aktuality Výzkumného a šlechtitelského ústavu okrasného zahradnictví v Průhonicích. Praha: Novinár. 198 p. (in Czech)

Cimbůrková, M., Šerá, B., 2011. Specifika vegetace kolem silnic a dálnic - problematika začlenění dřevin do volné krajiny. Životni prostředí, 45 (3) [online]. [cited 2014-10-31]. Retrieved from: http://147.213.211.222/sites/default/files/2011_3_162_165_cimburkova.pdf (in Czech) 
Hykš, O., Neubergová, K., 2014. Vzrostlá zeleň podél dopravních cest [Mature Vegetation along Roads]. In Jandová, V., Mikulová, I., Ličbinský, R. (eds.). VI Czech and Slovak Conference "Transport, Health and the Environment", Brno (Czech Republic), November 10-11, 2014. Brno: Transport Research Centre, pp. 177-184. ISBN 978-80-86502-85-4. (in Czech)

Neubergová, K., 2001. Funkce zeleně v našich městech. Veřejná správa, XII (16), pp. I - III. (in Czech)

Oneyama, H., Kawakami, A., Imai, R., Kosuge, T., 1999. A Possibility of Establishing the Ecologfical Network Using Road Space. Infrastructure and Transportation in the 21 Century. PIARC.

Policie ČR, 2014. Statistiky dopravních nehod [online]. C 2014 Policie ČR [cited 2014-10-31]. Retrieved from: http://www.policie.cz/clanek/statistika-nehodovosti-900835.aspx (in Czech)

Pradines, Ch., Marmier, F., 2011. Sécurité routière: véhicule-infrastructure-conducteur. Revue générale des routes et des aérodromes (RGRA), N. 891.

Simonová, E., Janata, M., Smělý, M., 2007. Problematika pasivní bezpečnosti pozemních komunikací. Část 1 - pevné překážky (stromy) Rakousko, Německo. Výstupy projektu Problematika pasivní bezpečnosti pozemních komunikací, VYPAB. Brno: CDV. (in Czech)

Skalský, M., 2010. Řidič v aleji intuitivně zpomalí. Ekolist.cz [online]. [cited 2014-10-31]. Retrieved from: http://ekolist.cz/cz/publicistika/nazory-a-komentare/martin-skalsky-ridicv-aleji-intuitivne-zpomali (in Czech)

Šerá, B., 2005. Roadsite Greenery in the Open Landscape. Životní prostředí [online]. 39 (4), pp. 208-211. [cited 2014-10-31]. Retrieved from:

http://147.213.211.222/sites/default/files/2005_4_208_211_sera.pdf (in Czech)

Švédová, D., 2010. Vegetační doprovod silnic, vliv na dopravní nehody a problémy s obnovou alejí. Zahrada-park-krajina [online]. (3) [cited 2014-10-31]. Retrieved from: http://www.zahrada-park-krajina.cz/ (in Czech)

Vysloužil, M., 2006. Historické aleje - cesty do historických zahrad. In Historické zahrady Kroměrižz 2006. Umění a společenská činnost v historických zahradách. Sborník vydaný u přiležitosti konáni odborného seminářre. Kroměřžž: Agentura Bonus, pp. 41-43. (in Czech)

NOTICE: The article was taken over from the proceedings of VI Czech and Slovak Conference "Transport, Health and the Environment" held on 10 - 11 November 2014 in Brno (Czech Republic), upon the decision of the proceedings publisher Transport Research Centre and with the consent of the authors of the article.

With the consent of the authors, the article was adapted on the basis of editing instructions of Transactions on Transport Sciences journal and translated into English language. 